\title{
Occurrence and Formation of the $N^{\epsilon}$-Methyl-lysines in Myosin and the Myofibrillar Proteins
}

\author{
BY MADELEINE F. HARDY, C. I. HARRIS, S. V. PERRY AND D. STONE \\ Department of Biochemistry, University of Birmingham, Birmingham, 15, U.K.
}

(Received 27 July 1970)

\begin{abstract}
1. Adult rabbit skeletal-muscle myosin has been shown to contain 1.0 residue of mono- $N^{\epsilon}$-methyl-lysine and 3.3 residues of tri- $N^{\epsilon}$-methyl-lysine per molecule of molecular weight 500000 . 2. The methyl-lysines appear to be located in the subfragment 1 portion of the myosin molecule. 3. Methyl-lysines are not present in actin, tropomyosin, inhibitory factor and calcium-sensitizing factor. 4. Enzymic methylation of histidine and lysine residues of myosin has been demonstrated in vitro. 5. The methylation of histidine and lysine of the total myofibrillar protein occurs after peptide-bond synthesis. 6. Although methylated lysines and 3-methylhistidine could not be detected by analysis of hydrolysates, radiochemical evidence is provided for the presence of these residues in the soluble-protein fraction of rabbit skeletal muscle.
\end{abstract}

During the investigation of the mechanism of formation of 3-methylhistidine in the myofibrillar proteins, mono- $N^{\epsilon}$-methyl-lysine was found to be present in the myofibril and in subfragment 1 of myosin (Hardy \& Perry, 1969). Independently Huszar \& Elzinga (1969) reported the presence of mono- $N^{\epsilon}$-methyl-lysine in myosin, although their analytical procedure did not resolve the three $N^{\epsilon}$. methyl derivatives of lysine. In the investigations of Hardy \& Perry (1969), an additional methylated amino acid, which by its elution characteristics was suspected to be one of the other $N$-methylated lysines, was shown to be present in appreciable quantities in hydrolysates of subfragment 1 of myosin. A radioactive component of identical elution characteristics to this additional methylated amino acid was also isolated from hydrolysates of whole myofibrils and sarcoplasm after labelling experiments in vitro with $S$-adenosyl-L-[ $\left.m e t h y l-{ }^{14} \mathrm{C}\right]$ methionine. It has now been shown that the unidentified methylated amino acid is tri- $N^{\epsilon}$-methyllysine, and that whereas only the mono- and tri- $N^{\epsilon}$ methyl-lysines occur in myosin these amino acids and di- $N^{\epsilon}$-methyl-lysine are present in hydrolysates of the whole myofibrillar-protein fraction.

These results have been briefly reported (Hardy, Harris, Perry \& Stone, 1970; Perry, 1969), and since the identification of the methyl-lysines was completed Kuehl \& Adelstein (1969) have also independently reported the occurrence of mono- and tri- $N^{\epsilon}$-methyl-lysine in myosin.

\section{METHODS}

Preparation of muscle proteins. Actin was prepared from acetone-dried rabbit skeletal-muscle fibre as described by Johnson, Harris \& Perry (1967).

Myosin was prepared by the method of Perry (1955) modified by the addition of $1 \mathrm{mM}-\mathrm{MgCl}_{2}$ and $10 \mathrm{~mm}$-sodium pyrophosphate to the buffer in which muscle mince was extracted, to minimize the extraction of actomyosin (Trayer \& Perry, 1966); 10 mm-2-mercaptoethanol was used throughout the preparation. Myosin was further purified by DEAE-cellulose chromatography (Perry, 1960). Only the material from the main peak eluted at $0.3 \mathrm{M}-\mathrm{KCl}$ in tris- $\mathrm{HCl}$ buffer, $\mathrm{pH} 8.2$, was used for amino acid analysis.

Subfragment 1. A solution of myosin $(15-20 \mathrm{mg} / \mathrm{ml})$ in $\quad 0.5 \mathrm{M}$-KCl-5 mM-cysteine-2 $\mathrm{mm}$-EDTA-15 mM-sodium phosphate buffer, $\mathrm{pH} 7.0$, was stirred for $10 \mathrm{~min}$ at $25^{\circ} \mathrm{C}$ with sufficient insoluble papain (Lowey, Slayter, Weeds \& Baker, 1969) to give a myosin: papain ratio $150: 1$. The insoluble papain was removed by centrifugation at $3000 \mathrm{~g}$ for $5 \mathrm{~min}$ at $4^{\circ} \mathrm{C}$, and the supernatant further clarified by centrifugation at $70000 \mathrm{~g}$ for $30 \mathrm{~min}$.

The supernatant was dialysed overnight against 10 volumes of $10 \mathrm{~mm}$-2-mercaptoethanol-5 mM-sodium phosphate buffer, $\mathrm{pH} 7.0$, and the material precipitated at low ionic strength was removed by centrifugation at $70000 \mathrm{~g}$ for $45 \mathrm{~min}$.

The supernatant was concentrated by ultrafiltration and fractionated on a column $(2.5 \mathrm{~cm} \times 100 \mathrm{~cm})$ of Sephadex G-200 (Pharmacia) equilibrated with $10 \mathrm{~mm}$-2-mercaptoethanol-25 mM-tris- $\mathrm{HCl}, \mathrm{pH} 7.6$, at $4^{\circ} \mathrm{C}$. The column was eluted at $15 \mathrm{ml} / \mathrm{h}$ and fractions $(5 \mathrm{ml})$ were collected. The fractions with the highest specific adenosine triphosphatase activity were pooled for subfragment 1 preparations. 
Incorporation of ${ }^{14} \mathrm{C}$ in myofibrillar protein. Muscle homogenate prepared from longissinus dorsi of 5-dayold rabbits with 2-3 volumes of ice-cold $0.25 \mathrm{M}$-sucrose was incubated in a medium containing $2 \mathrm{mM}-\mathrm{MgCl}_{2}$, $50 \mathrm{~mm}$-tris-HCl, pH 7.8, $50 \mathrm{~mm}-\mathrm{KCl}, 100 \mu \mathrm{M}-S$-adenosyl$\mathrm{L}-\left[\right.$ methyl $\left.-{ }^{14} \mathrm{C}\right]$ methionine $(40 \mu \mathrm{Ci} / \mu \mathrm{mol})$ and $4 \mathrm{~mm}-2$ mercaptoethanol. The volume of homogenate was varied depending on the amount of muscle protein used, which ranged from 5 to $50 \mathrm{mg}$ according to the nature of the experiment.

After incubation at $34^{\circ} \mathrm{C}$ for up to $4 \mathrm{~h}$, the homogenate was fractionated into a myofibrillar and a sarcoplasmicgranular fraction by centrifugation at $800 \mathrm{~g}$ for $10 \mathrm{~min}$, and the sarcoplasmic-granular fraction was further separated into crude granular fraction and sarcoplasm by centrifugation at $100000 \mathrm{~g}$ for $1 \mathrm{~h}$. The myofibrils were washed with $0.1 \mathrm{M}-\mathrm{KCl}-39 \mathrm{~mm}$-sodium borate buffer, pH 7.0 (Perry \& Zydowo, 1959), and further purified on a sucrose gradient (Saide, Kayne \& Ulbrick, 1968). Myosin was extracted from the myofibrils, and the nucleoprotein that is always associated with foetal and neonatal myosin was removed by chromatography on DEAE-Sephadex (Richards, Chung, Menzel \& Olcott, 1967). The cell fractions were precipitated with an equal volume of $25 \%$ $(w / v)$ trichloroacetic acid. After treatment to remove nucleic acid and phospholipid (Manchester \& Young, 1958) the protein was either dissolved in $0.3 \mathrm{M}$-Hyamine hydroxide in methanol in air-tight tubes at $60^{\circ} \mathrm{C}$ for $12 \mathrm{~h}$ or hydrolysed in $6 \mathrm{M}-\mathrm{HCl}$ as described below. The Hyaminesolubilized protein, which was used for measurement of the total incorporation of ${ }^{14} \mathrm{C}$ into the cell fraction, was dissolved in scintillation fluid [ $4 \mathrm{~g}$ of 2,5 -diphenyloxazole and $0.05 \mathrm{~g}$ of 2 -p -phenylene-bis-(5-phenyloxazole)/l of toluene] and counted in a Nuclear-Chicago scintillation counter, model Unilux II.

Determination of mono- $\mathrm{N}^{\epsilon}$-methyl-lysine and tris- $\mathrm{N}^{\epsilon}$ methyl-lysine. Samples of protein for analysis were precipitated with an equal volume of $25 \%(\mathrm{w} / \mathrm{v})$ trichloroacetic acid, the precipitate was dissolved in dilute alkali $(0.05 \mathrm{M}-\mathrm{NaOH})$, the trichloroacetic acid was removed by repeated ether extraction, and the protein was reprecipitated with an equal volume of aq. $95 \%$ ethanol. The etherdried protein was hydrolysed at $110^{\circ} \mathrm{C}$ for $24 \mathrm{~h}$ in $6 \mathrm{M}-\mathrm{HCl}$ in an evacuated sealed tube, as recommended by Moore \& Stein (1963). After hydrolysis the $\mathrm{HCl}$ was rapidly removed by rotary evaporation and the hydrolysate, $5-8 \mathrm{mg}$ of myosin and other proteins or $2-3 \mathrm{mg}$ of subfragment 1 , was applied to a column $(0.9 \mathrm{~cm} \times 53 \mathrm{~cm})$ of Beckman UR resin. Analysis was carried out on a Beckman Unichrom analyser with $0.35 \mathrm{~m}$-sodium citrate buffer, pH 5.28 at $55^{\circ} \mathrm{C}$ (Murray, 1964), in which system in the absence of di- $N^{\epsilon}$-methyl-lysine, mono- $N^{\epsilon}$-methyl-lysine and tri- $N^{\epsilon}$-methyl-lysine were resolved and could be accurately measured. For resolution of all three methyllysines, 0.35 M-sodium citrate buffer, pH5.79 at $28^{\circ} \mathrm{C}$ (Paik \& Kim, 1967), was used. The flow rate was $40 \mathrm{ml} / \mathrm{h}$ in each case.

Identification of radioactive amino acids. (a) High-voltage electrophoresis. Paper electrophoresis was carried out on Whatman 3MM paper on a horizontal cooled plate at

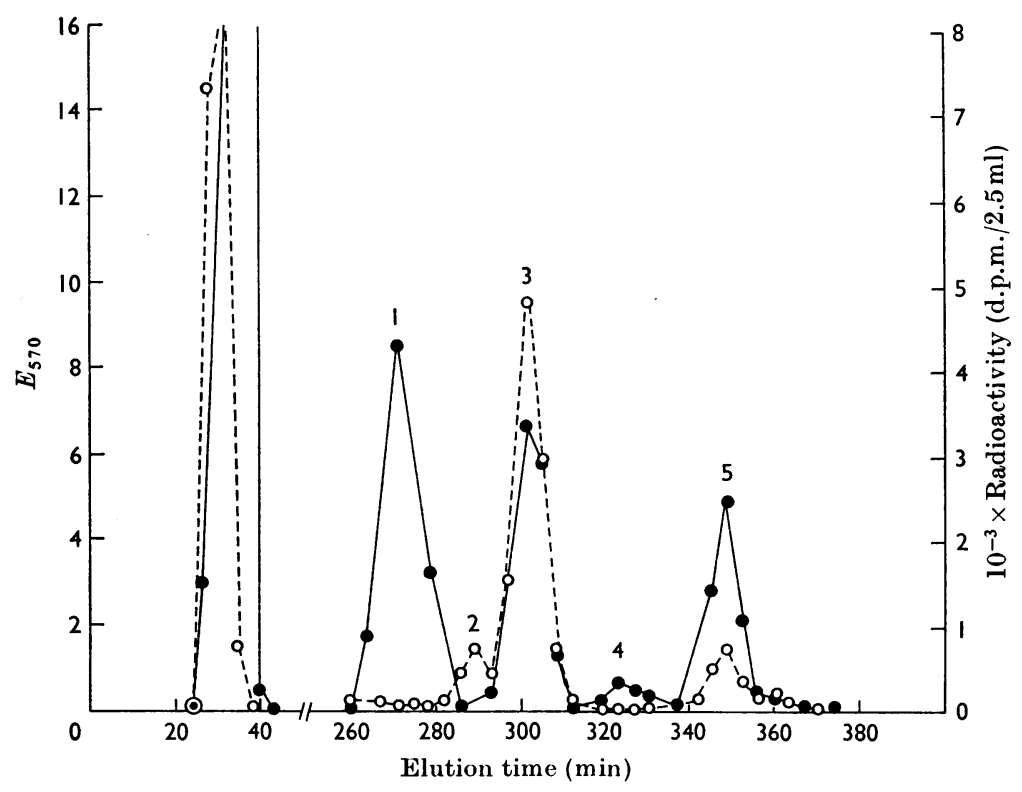

Fig. 1. Column chromatography at pH5.28 of the acid hydrolysate of the myofibrillar fraction isolated from muscle homogenate incubated with ${ }^{14} \mathrm{C}$-labelled $S$-adenosyl-L-methionine. Mono- $N^{\epsilon}$-methyl-lysine $(5.0 \mu \mathrm{mol})$ and 3-methylhistidine $(5.0 \mu \mathrm{mol})$ were added to the hydrolysate, and the amino acids were eluted with $0.35 \mathrm{M}$ sodium citrate buffer, pH5.28 at $55^{\circ} \mathrm{C}$. Fractions $(2.5 \mathrm{ml})$ were collected. Peaks: 1 , lysine; 2 , tri- $N^{\epsilon} \cdot$ methyllysine; 3, mono- $N^{\epsilon}$-methyl-lysine; 4, histidine; 5, 3-methylhistidine. $\bullet$, Amino acid determination by the ninhydrin method $\left(E_{570}\right)$; O, radioactivity (d.p.m./2.5 ml). 
pH 6.5 [5\% (v/v) pyridine- $0.2 \%(\mathrm{v} / \mathrm{v})$ acetic acid $]$ with a potential gradient of $30 \mathrm{~V} / \mathrm{cm}$.

(b) Amino acid analysis. Up to $25 \mathrm{mg}$ of hydrolysed protein was applied to a column of the Beckman Unichrom analyser and the column developed with the buffer systems previously described. Fractions $(2.5 \mathrm{ml})$ were collected and assayed for radioactivity with a toluene-Triton phosphor scintillator $(6 \mathrm{ml}$ of scintillation fluid, $3 \mathrm{ml}$ of Triton X-100 and $1 \mathrm{ml}$ of aqueous extract) and for amino acid by development of ninhydrin colour (Rosen, 1957).

(c) Paper chromatography. The ${ }^{14} \mathrm{C}$-labelled amino acids eluted from the Beckman analyser column were chromatographed on Whatman 3 MM paper in $n$-propanolaq. $35 \%$ ammonia $(67: 33, v / v)$ as solvent (Kuehl \& Adelstein, 1969).

$\mathrm{N}^{\epsilon}$-Methyl-lysines. Mono- $N^{\epsilon}$-methyl-lysine was supplied by Calbiochem, Los Angeles, Calif., U.S.A. Tri- $N^{\epsilon}$-methyllysine was made by the method of DeLange, Glazer \& Smith (1969). Samples of di- and tri- $N^{\epsilon}$-methyl-lysine were also kindly supplied by Dr R. J. DeLange.

\section{RESULTS}

After incubation of muscle homogenates with $S$-adenosyl-L- $\left[\right.$ methyl- $\left.{ }^{14} \mathrm{C}\right]$ methionine, two peaks of radioactivity (peaks 2 and 3, Fig. 1) were eluted in addition to that associated with 3-methylhistidine when hydrolysates of the whole myo- fibrillar protein fraction were analysed on the Beckman Unichrom instrument by elution with $0.35 \mathrm{M}$-sodium citrate buffer, $\mathrm{pH} 5.28$ at $55^{\circ} \mathrm{C}$. From the published data (DeLange et. al. 1969), peak 2 corresponded to tri- $N^{\epsilon}$-methyl-lysine and peak 3 corresponded to the position of elution of a known sample containing mono- $N^{\epsilon}$-methyllysine and di- $N^{\epsilon}$-methyl-lysine. Although the peaks of radioactivity were clearly defined, the relative amounts of the methylated lysines present in the whole myofibrillar fraction were low and could only be picked up as separate detectable ninhydrin peaks when relatively large amounts of hydrolysate were applied to the analyser column.

Better resolution of the methyl-lysines was obtained by elution with $0.35 \mathrm{M}$-sodium citrate buffer, pH 5.79 (Paik \& Kim, 1967), when hydrolysates of the myofibrillar protein were resolved into three peaks of radioactivity between the lysine and histidine peaks. These peaks were shown to have identical elution rates to known samples of mono$N^{\epsilon}$-methyl-lysine, di- $N^{\epsilon}$-methyl-lysine and tri$N^{\epsilon}$-methyl-lysine respectively (Fig. 2).

In view of these observations and the fact that the radioactivity implies the presence of methyl groups in the ninhydrin peaks in each case, it was

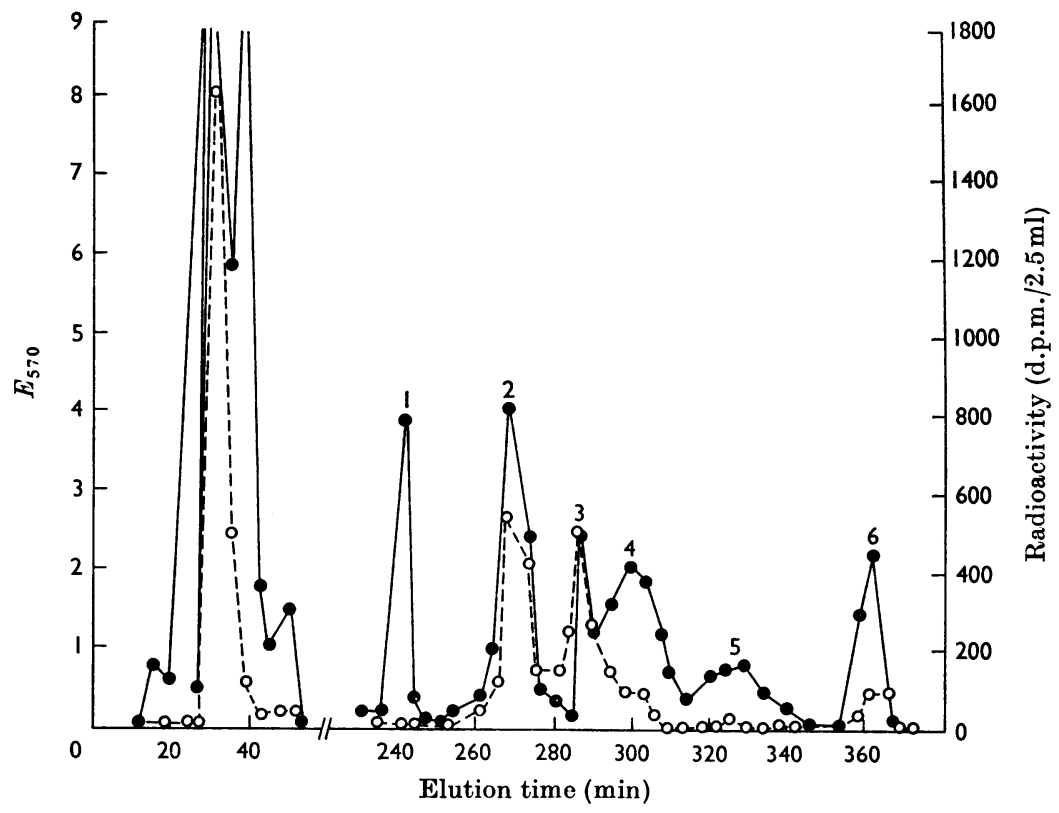

Fig. 2. Column chromatography at pH5.79 of the acid hydrolysate of the myofibrillar fraction isolated from muscle homogenate incubated with ${ }^{14} \mathrm{C}$-labelled $S$-adenosyl-L-methionine. Mono-, di- and tri- $N^{\epsilon}$-methyl-lysine $(5.0 \mu \mathrm{mol}$ of each) were added to the hydrolysate, and the amino acids were eluted with $0.35 \mathrm{M}$-sodium citrate buffer, pH5.79 at $28^{\circ} \mathrm{C}$. Fractions were collected and assayed for radioactivity and amino acids as described in Fig. 1. Peaks: 1, lysine;2, mono- $N^{\epsilon}$-methyl-lysine; 3, di- $N^{\epsilon}$-methyl-lysine; 4, tri- $N^{\epsilon}$-methyl-lysine; 5, histidine; $6, \mathrm{NH}_{3}$ and 3-methylhistidine. $\bullet, E_{570} ; \mathrm{O}$, radioactivity (d.p.m./2.5 ml). 


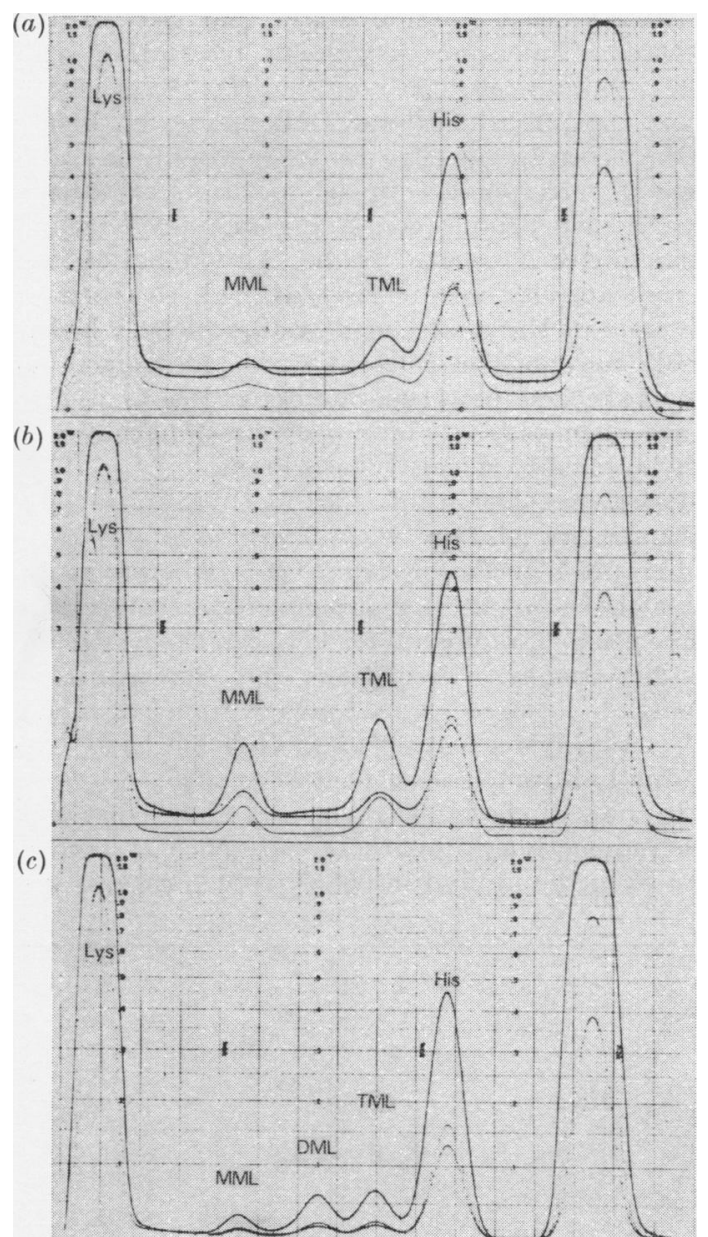

Fig. 3. Elution profile of subfragment 1 on the Beckman Unichrom analyser in $0.35 \mathrm{M}$-sodium citrate buffer, $\mathrm{pH} 5.79$ at $28^{\circ} \mathrm{C}$. (a) Subfragment 1 (3 mg). (b) Subfragment 1 $(3 \mathrm{mg})+0.05 \mu \mathrm{mol}$ of each of mono- $N^{\epsilon}$-methyl-lysine (MML) and tri- $N^{\epsilon}$-methyl-lysine (TML). (c) Subfragment 1 (3 mg) $+0.02 \mu \mathrm{mol}$ of di- $N^{\epsilon}$-methyl-lysine (DML). concluded that the myofibril contained proteinbound mono- $N^{\epsilon}$-methyl-lysine, di- $N^{\epsilon}$-methyl-lysine and tri- $N^{\epsilon}$-methyl-lysine. This conclusion was supported by the observation that the radioactive methyl-lysines isolated from hydrolysates of the myofibrillar protein behaved in an identical way on chromatography in $n$-propanol-aq. $35 \%$ ammonia $(67: 33, \mathrm{v} / \mathrm{v})$ to known samples of mono- $N^{\epsilon}$-methyllysine, di- $N^{\epsilon}$-methyl-lysine and tri- $N^{\epsilon}$-methyllysine respectively.

Methyl-lysines in myosin and subfragment 1. Hydrolysates of myosin isolated from rabbit white skeletal muscle gave ninhydrin peaks corresponding to mono- $N^{\epsilon}$-methyl-lysine and tri- $N^{\boldsymbol{\epsilon}}$-methyl-lysine, although the amounts compared with those of the other amino acids were small and difficult to measure with accuracy. Analysis of subfragment 1 isolated from myosin by papain digestion suggested that, as is the case with 3-methylhistidine, most if not all of the methyl-lysines was present in this part of the molecule. On elution of hydrolysates of subfragment 1 in the analytical system at $\mathrm{pH} \mathrm{5.79,}$ it was shown that the ninhydrin peaks appearing after lysine had elution rates identical with those of known samples of mono- $N^{\epsilon}$-methyl-lysine and tri- $N^{\epsilon}$-methyl-lysine (Fig. 3). In no preparation of subfragment 1 or myosin was any di- $N^{\epsilon}$-methyllysine detected. Radioactive mono- and $\mathrm{di}-\mathrm{N}^{\epsilon}$. methyl-lysine were detected, however, in the nucleoprotein fraction (Perry, 1960) separated by chromatography on DEAE-Sephadex from myosin isolated from the 5-day-old rabbit. None of the methyl-lysines was found in any of the other myofibrillar proteins analysed, actin, tropomyosin, inhibitory factor and calcium-sensitizing factor (Table 1). They were also absent from the lowmolecular-weight components of myosin isolated as described by Perrie \& Perry (1970).

Methylation of myosin in vitro. The results of the analysis of the myofibrillar proteins and the myofibrils, taken with the radiochemical studies on the latter, suggested that di- $N^{\epsilon}$-methyl-lysine at

Table 1. Amounts of $\mathrm{N}^{\epsilon}$-methyl-lysines in rabbit myofibrillar proteins

The content of methylated lysines in myofibrils was calculated on the basis of methyl-lysine/histidine ratios, given that the myofibril contains $14.1 \% \mathrm{~N}$ (Perry, 1952) and $13.75 \mathrm{~mol}$ of histidine $/ 10^{5} \mathrm{~g}$.

$N^{\epsilon}$-Methyl-lysines (mol/10 $10^{5} \mathrm{~g}$ of protein)

\section{Protein}

Myosin (adult skeletal)

Myosin (foetal)

Subfragment 1

Myofibrils*
No. of preparations

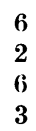

2

6

3

\begin{tabular}{lll}
\multicolumn{1}{c}{ Mono- } & Di- & \multicolumn{1}{c}{ Tri- } \\
$0.20( \pm 0.06)$ & Nil & $0.66( \pm 0.10)$ \\
0.10 & Nil & 0.58 \\
$0.59( \pm 0.066)$ & Nil & $1.75( \pm 0.3)$ \\
0.087 & Nil & 0.22
\end{tabular}

* Isolated from adult rabbit white skeletal muscle. 


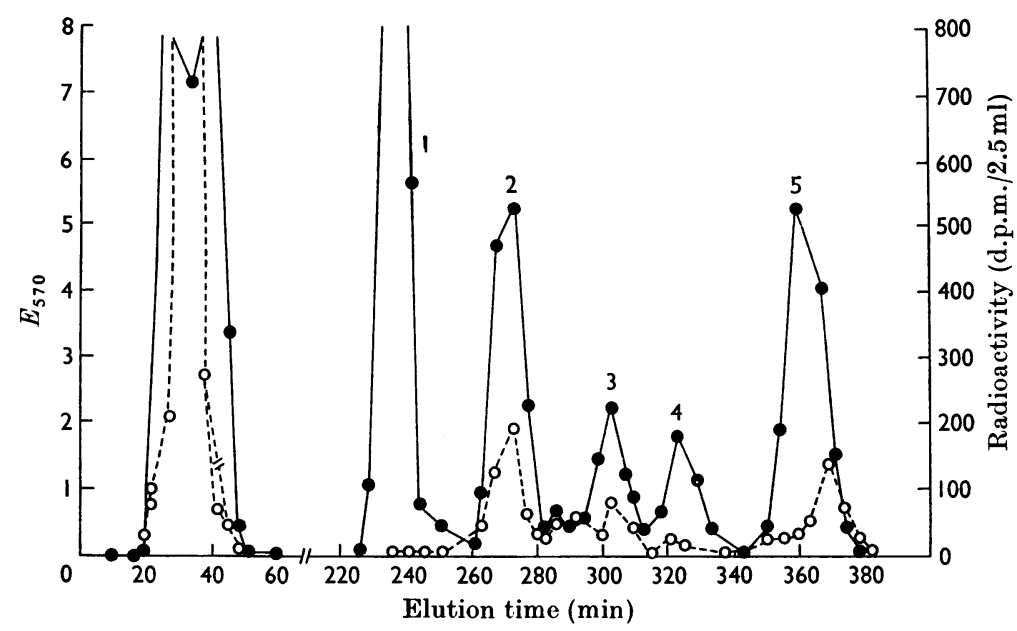

Fig. 4. Column chromatography of the acid hydrolysate of myosin isolated from muscle homogenate incubated with ${ }^{14} \mathrm{C}$-labelled $S$-adenosyl-L-methionine. Mono- and tri- $N^{\epsilon}$-methyl-lysine $(5.0 \mu \mathrm{mol}$ of each) were added to the hydrolysate. The amino acids were eluted with $0.35 \mathrm{~m}$-sodium citrate buffer, $\mathrm{pH} 5.79$ at $28^{\circ} \mathrm{C}$, and the fractions collected and assayed for amino acid and radioactivity as described in Fig. 1. Peaks: 1, lysine; 2, mono$N^{\epsilon}$-methyl-lysine; 3 , tri- $N^{\epsilon}$-methyl-lysine; 4 , histidine; $5, \mathrm{NH}_{3}$ and 3 -methylhistidine. $\bullet, E_{570} ;$ ○, radioactivity (d.p.m./2.5 ml).

least was present in proteins other than the wellcharacterized components of the myofibril. Therefore, to confirm that the lysine of myosin was in fact being methylated in the system in vitro, this protein was isolated from myofibrils purified by sucrose zone centrifugation after isolation from homogenates incubated with ${ }^{14} \mathrm{C}$-labelled $S$-adenosyl-L-methionine. Fig. 4 shows that hydrolysates of the myosin from which possible nucleoprotein contamination had been removed by chromatography in DEAEcellulose contained significant although small amounts of radioactivity coincident with the ninhydrin peaks obtained by adding known samples of mono- $N^{\epsilon}$-methyl-lysine and 3-methylhistidine. The very small amounts of radioactivity in the region where di- $N^{\epsilon}$-methyl-lysine and $\operatorname{tri}-N^{\epsilon}$. methyl-lysine were eluted were not significant.

Control experiments established that the methylation of the histidine and lysine of the total myofibrillar protein was an enzymic process, for no incorporation occurred when the homogenate was heated for $10 \mathrm{~min}$ before incubation with ${ }^{14} \mathrm{C}$ labelled $S$-adenosyl-L-methionine. A further control to exclude the possibility of non-enzymic methylation of protein-bound lysine and histidine was carried out by incubating $20 \mathrm{mg}$ of subfragment 1 for $12 \mathrm{~h}$ with $5 \mu \mathrm{Ci}$ of ${ }^{14} \mathrm{C}$-labelled $S$-adenosyl-Lmethionine in tris- $\mathrm{HCl}, \mathrm{pH} 7.8$, alone. Amino acid analysis of the subfragment 1 treated in this way, and subsequently subjected to the usual procedures to remove non-covalently bound material, indicated that no radioactivity was associated with the mono- $N^{\epsilon}$-methyl-lysine and tri- $N^{\epsilon}$-methyl-lysine or 3-methylhistidine peaks. However, radioactivity (600d.p.m./mg of protein) was present in the combined acidic and neutral amino acid fraction, presumably owing to methionine or its oxidation products produced during fractionation. In view of the absence of protein synthesis in this system the results suggest that non-enzymic exchange had occurred between the methyl group of methionine residues in the myosin molecule and the corresponding labelled group in the radioactive $S$-adenosyl-Lmethionine or L-methionine derived from it.

Location of methylating systems in skeletal-muscle homogenates. In preliminary experiments to determine the location of the enzymic system or systems responsible for methylating lysine and histidine residues of the myofibrillar proteins, it was evident that significant incorporation of the radioactivity of ${ }^{14} \mathrm{C}$-labelled $S$-adenosyl-L-methionine occurred in other muscle fractions as well as in the myofibrils. Fig. 5 illustrates the results of a study of the incorporation of ${ }^{14} \mathrm{C}$ into the two crude fractions of rabbit skeletal muscle. Incorporation in the total homogenate increased steadily for up to $8 \mathrm{~h}$, but normally an incubation time of $4 \mathrm{~h}$ was used in the standard experiments for studying the incorporation into the methylated amino acids.

The extent of the total incorporation of radioactivity into the muscle fractions was not a direct index of methylation of lysine and histidine for, as Figs. 1 and 2 indicate, a large fraction of the ${ }^{14} \mathrm{C}$ was found in the combined acidic and neutral 
fraction of amino acids from the protein hydrolysates. Further chromatographic fractionation of the combined acidic and neutral amino acid fraction from the protein hydrolysates indicated that this

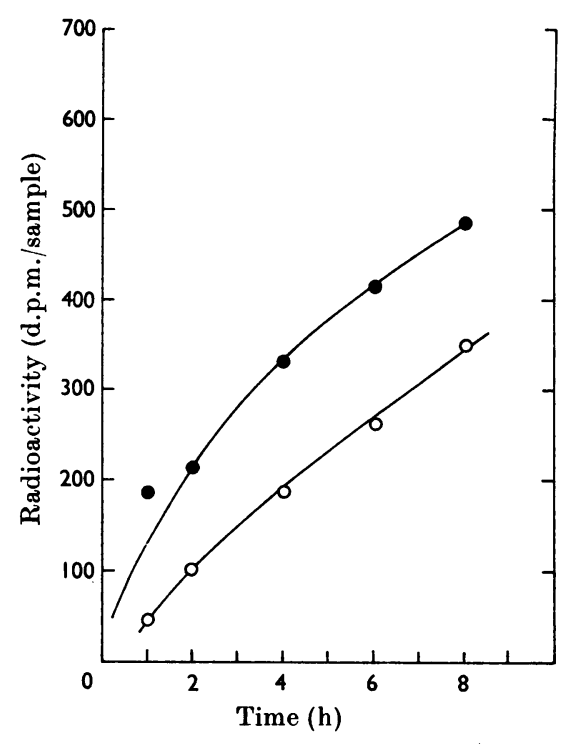

Fig. 5. Time-course of incorporation of ${ }^{14} \mathrm{C}$ into the myofibrillar and soluble-protein fractions isolated from muscle homogenate incubated with $S$-adenosyl-L-[methyl $\left.-{ }^{14} \mathrm{C}\right]$ methionine. Muscle homogenate $(10 \mathrm{mg})$ was incubated with $100 \mu \mathrm{M}$-S -adenosyl-L-methionine $(0.2 \mu \mathrm{Ci})$ in $50 \mathrm{~mm}$ -

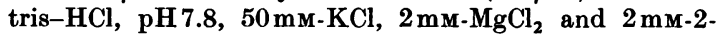
mercaptoethanol. ๑, Myofibrillar protein; $O$, soluble protein. was accounted for mainly by the oxidized derivatives of methionine. It was therefore concluded that the radioactivity in this fraction was due to $\left[{ }^{14} \mathrm{C}\right]$-methionine produced by breakdown of ${ }^{14} \mathrm{C}$ labelled $S$-adenosyl-L-methionine that had been incorporated by protein synthesis (see below). The possibility of some non-enzymic exchange cannot, however, be ruled out (see above).

In view of these observations and the effect of puromycin described below, the extent of ${ }^{14} \mathrm{C}$ incorporation in the combined neutral and acidic fraction and the basic amino acid fraction were taken as approximate indices of protein synthesis and protein methylation respectively. On this basis it can be seen from Table 2 that, whereas in the myofibrillar fraction roughly about half of ${ }^{14} \mathrm{C}$ incorporation was due to protein synthesis, the major part of the ${ }^{14} \mathrm{C}$ incorporation in the microsome and soluble-protein fractions was due to methylation of lysine and histidine. Incorporation into the microsome fraction, which in rabbit muscle consists of a mixture of sarcoplasmic reticulum and mitochondria, was significant, but $80-90 \%$ of the total incorporation was accounted for by the myofibrillar and soluble-protein fractions.

Despite the identification of radioactive lysines, especially the mono- $N^{\epsilon}$-methyl-lysine and the tri- $N^{\epsilon}$-methyl-lysine and 3-methylhistidine in the soluble protein fraction, these amino acids could not be detected on amino acid analysis of the soluble protein fraction when the usual amounts of hydrolysate were applied to the column. Preliminary results that are currently being extended have shown that methylation was confined to certain fractions of the sarcoplasmic protein.

Table 2. Distribution of ${ }^{14} \mathrm{C}$ incorporation between the combined acidic and neutral and the basic fractions of hydrolysates of protein of the intracellular fractions of rabbit skeletal muscle

The values are percentages of the total radioactivity incorporated found in a particular fraction after incubation.

\begin{tabular}{|c|c|c|c|c|c|}
\hline \multirow[b]{2}{*}{ Type of homogenate } & & \multirow{2}{*}{$\begin{array}{l}\text { Amino acid } \\
\text { fraction }\end{array}$} & \multicolumn{3}{|c|}{ Radioactivity (\% of total) } \\
\hline & & & Myofibrils & Microsomal & Soluble protein \\
\hline $\begin{array}{l}\text { Whole skeletal muscle from } \\
\text { a 4-day-old rabbit }\end{array}$ & (1) & $\begin{array}{l}\text { Acidic } \\
\text { Basic }\end{array}$ & $\begin{array}{l}54 \\
46\end{array}$ & & $\begin{array}{l}30 \\
70\end{array}$ \\
\hline & $(2)$ & $\begin{array}{l}\text { Acidic } \\
\text { Basic }\end{array}$ & $\begin{array}{l}44 \\
56\end{array}$ & $\begin{array}{l}21 \\
79\end{array}$ & $\begin{array}{l}38 \\
62\end{array}$ \\
\hline & (3) & $\begin{array}{l}\text { Acidic } \\
\text { Basic }\end{array}$ & $\begin{array}{l}56 \\
44\end{array}$ & $\begin{array}{l}21 \\
79\end{array}$ & $\begin{array}{l}55 \\
45\end{array}$ \\
\hline $\begin{array}{l}\text { Whole skeletal muscle from } \\
\text { an adult rabbit }\end{array}$ & & $\begin{array}{l}\text { Acidic } \\
\text { Basic }\end{array}$ & $\begin{array}{l}73 \\
27\end{array}$ & & \\
\hline Myosin* + soluble protein $\dagger$ & & $\begin{array}{l}\text { Acidic } \\
\text { Basic }\end{array}$ & $\begin{array}{l}83 \ddagger \\
17 \ddagger\end{array}$ & & $\begin{array}{l}20 \\
80\end{array}$ \\
\hline
\end{tabular}

* Isolated from the skeletal muscle of a 4-day-old rabbit.

$\dagger$ Isolated from the skeletal muscle of a 3-week-old rabbit.

$\ddagger$ Distribution measured in hydrolysates of myosin. 
Table 3. Effect of puromycin on the incorporation of ${ }^{14} \mathrm{C}$ into myofibrillar protein isolated from muscle homogenates incubated with S-adenosyl-L- $\left[\right.$ methyl $\left.-{ }^{14} \mathrm{C}\right]$ methionine

\begin{tabular}{|c|c|c|c|}
\hline \multirow{3}{*}{$\begin{array}{c}\text { Expt. no. } \\
1\end{array}$} & \multirow{3}{*}{$\begin{array}{l}\text { Amino acid fraction } \\
\text { Acidic + neutral } \\
\text { Total methylated amino acids }\end{array}$} & \multicolumn{2}{|c|}{ Radioactivity incorporated (d.p.m./mg*) } \\
\hline & & Control incubation & $\begin{array}{l}\text { Incubation with } \\
1.0 \text { mM-puromycin }\end{array}$ \\
\hline & & $\begin{array}{l}1044 \\
2850\end{array}$ & $\begin{array}{r}117 \\
2364\end{array}$ \\
\hline 2 & $\begin{array}{l}\text { Acidic }+ \text { neutral } \\
\text { Total methylated amino acids }\end{array}$ & $\begin{array}{r}1151 \\
671\end{array}$ & $\begin{array}{l}229 \\
792\end{array}$ \\
\hline
\end{tabular}

Protein synthesis and methylation. By analogy with hydroxylating (Udenfriend, 1966) and other methylating systems (Comb, Sarkar \& Pinzino, 1966; Tidwell, Allfrey \& Mirsky, 1968; Allfrey, Faulkner \& Mirsky, 1964) it would be expected that methylation of lysine and histidine occurred after peptide-bond formation. That this was indeed the case was indicated by the fact that when incubation of whole muscle homogenate was carried out in the presence of puromycin the extent of incorporation of the ${ }^{14} \mathrm{C}$-labelled methyl group in lysine and histidine was relatively little affected whereas the net protein synthesis was decreased by about $70 \%$ (Table 3). Protein synthesis was measured by the extent of incorporation of ${ }^{14} \mathrm{C}$ in the neutral and acidic amino acid fraction (see above).

\section{DISCUSSION}

The identification of mono- and tri- $N^{\epsilon}$-methyllysine brings the total of methylated amino acids present in myosin to three. In this respect myosin is unique, for as yet methylated lysines and histidine have not been reported to occur together in any other protein (apart from the recent detection of methyllysines and 3-methylhistidine in histone fractions from immature erythroid cells of the duck; Gershey, Haslett, Vidali \& Allfrey, 1969). As in the case of 3-methylhistidine, the methyl-lysines are located in that part of the heavy chain present in the subfragment 1 portion of the myosin molecule. The mean of our analytical results and those of Kuehl \& Adelstein (1969) indicates that there are 1.2 residues of mono$N^{\epsilon}$-methyl-lysine per myosin molecule of molecular weight 500000 . As it is unlikely that this figure is so much in error that the real value is the whole number 2 , it implies that the myosin molecules may not be all identical. For if the two heavy chains of myosin possess identical sequences then two species of molecule must exist, some that have specific lysine residues in each heavy chain methylated and others that do not. If, however, there is only one residue of mono- $N^{\epsilon}$-methyl-lysine per molecule and all molecules are identical, it is necessary to postulate that only one of the otherwise identical heavy chains is methylated. Other possibilities may also occur in which some myosin molecules have more than one methyl-lysine residue per heavy chain. Heterogeneity of methylation is also suggested by the rather wide scatter in the values of the mono- $N^{\epsilon}$-methyllysine content of myosin and the fact that the subfragment 1 from adult rabbit skeletal-muscle myosin contains about 0.59 residue of mono- $N^{\epsilon}$-methyllysine per molecule. The arguments about the heterogeneity of methylation of myosin apply with particular force to the histidine residues of myosin isolated from skeletal muscle of young animals or red muscle of adult animals, which contains 0-1.6 residues of 3-methylhistidine per molecule depending on the stage of development and type of muscle (Trayer, Harris \& Perry, 1968).

If each myosin molecule gives rise to 2 molecules of subfragment 1, then from our results the subfragment 1 part of the molecule accounts for rather more mono- $N^{\epsilon}$-methyl-lysine than direct analysis indicates was present in the original myosin molecule. This observation is in direct contrast with the data of Kuehl \& Adelstein (1969), which indicate that a significant fraction of the mono- $N^{\epsilon}$-methyllysine is lost during subfragment 1 formation. The explanation of this discrepancy is uncertain, but our results can be explained as being due either to errors in measuring the small amounts of mono- $N^{\epsilon}$ methyl-lysine in myosin, or to a preferential loss during preparation of the subfragment 1 derived from myosin molecules of low content of mono- $N^{\epsilon}$. methyl-lysine. Similar but less striking discrepancies are apparent when the 3-methylhistidine contents of myosin and subfragment 1 are compared (Johnson et al. 1967; Stone, 1970).

Although di- $N^{\epsilon}$-methyl-lysine is absent from rabbit skeletal-muscle myosin, it is present, as judged by the radiochemical analysis, in the whole myofibrillar protein. The amounts are small, however, for it cannot be detected by direct amino acid analysis. None of the methyl-lysines was present in the other well-characterized myofibrillar proteins analysed, which together with the myosin account for about $90 \%$ of the total protein. 
Indeed the total mono- and tri- $N^{\epsilon}$-methyl-lysine present in the myofibril would be accounted for by a content of $43 \%$ and $33 \%$ respectively of myosin. The latter value in particular is considerably lower than the accepted value for the myosin content of the myofibril. Irrespective of the interpretation put on this apparent discrepancy, it appears that the myosin content accounts for all the mono- and tri- $N^{\epsilon}$-methyl-lysine found in the whole myofibril.

Although methylation of lysine and histidine in the myofibrillar protein fraction is clearly enzymic, non-enzymic transfer of radioactivity from $\mathrm{L}-\left[{ }^{14} \mathrm{C}\right]$ methionine to subfragment 1 can occur. The nature of the residues that are labelled nonenzymically has not been investigated fully but it seems likely that the methionine undergoes exchange. Asit is possible that the intensity of labelling might be increased by changing the conditions, this observation could have application for identification of methionine-containing peptides in sequence studies.

The nature of the enzymic system involved in methylation of protein-bound lysine has not yet been determined, but is presumably similar to that responsible for lysine methylation in histones and flagellin reported by others (Comb et al. 1966; Tidwell et al. 1968; Allfrey et al. 1964). It is not certain whether the same enzyme is responsible for methylation of lysine and histidine, but in both cases methylation occurs after peptide-bond synthesis. The possibility that the enzymic systems are different is suggested by the fact that lysine residues of myosin are methylated at an earlier stage of development of the muscle than is the case with the histidine. Whereas mono- and tri- $N^{\epsilon}$-methyllysines are present in myosin isolated from skeletal muscle of foetal rabbits, 3-methylhistidine is not. This evidence, however, does not necessarily imply the absence of the histidine-methylating system from foetal muscle, for in contrast with the situation with myosin, 3-methylhistidine is present in actin isolated from both foetal and adult muscle. Thus it appears that the enzyme system is present at an early stage of development and the presence of 3-methylhistidine depends on the existence of histidine residues in the protein susceptible to methylation. The results strongly suggest that changes occur in the structure of the myosin molecule during development.

The absence of di- $N^{\epsilon}$-methyl-lysine from rabbit myosin, although this residue has been found in other proteins, e.g. calf thymus histone and flagellin, emphasizes the special features of the methylation system for myosin in that it produces only mono- and tri- $N^{\epsilon}$-methyl-lysines without significant amounts of the intermediate methylated derivative.

Although in this study attention has been directed to the methylation of the myofibrillar proteins, preliminary studies indicate that significant methylation of lysine and histidine can occur in other fractions of muscle. These observations may reflect early stages in the biosynthesis of myofibrillar proteins that occur outside the myofibril, but perhaps a more likely explanation is that there is a wider distribution of the methylated amino acids in proteins than was previously supposed.

This work was supported in part by research grants from the Medical Research Council and the Muscular Dystrophy Associations of America, Inc.

\section{REFERENCES}

Allfrey, V. G., Faulkner, R. \& Mirsky, A. E. (1964). Proc. natn. Acad. Sci. U.S.A. 51, 786.

Comb, D. G., Sarkar, N. \& Pinzino, C. J. (1966). J. biol. Chem. 241, 1857.

DeLange, R. J., Glazer, A. N. \& Smith, E. L. (1969). J. biol. Chem. 244, 1385.

Gershey, E. L., Haslett, G. W., Vidali, G. \& Allfrey, V. G. (1969). J. biol. Chem. 244, 4871.

Hardy, M. F., Harris, C. I., Perry, S. V. \& Stone, D. (1970). Biochem. J. 117, 44 P.

Hardy, M. F. \& Perry, S. V. (1969). Nature, Lond., 223, 300.

Huszar, G. \& Elzinga, M. (1969). Nature, Lond., 223, 834.

Johnson, P., Harris, C. I. \& Perry, S. V. (1967). Biochem.J. 105, 361.

Kuehl, M. W. \& Adelstein, R. S. (1969). Biochem. biophys. Res. Commun. 37, 59.

Lowey, S., Slayter, H. W., Weeds, A. G. \& Baker, H. (1969). J. molec. Biol. 42, 1.

Manchester, K. L. \& Young, F. G. (1958). Biochem. J. 70, 353.

Moore, S. \& Stein, W. H. (1963). In Methods in Enzymology, vol. 4, p. 819. Ed. by Colowick, S. P. \& Kaplan, N. O. New York: Academic Press Inc.

Murray, K. (1964). Biochemistry, Easton, 3, 10.

Paik, W. K. \& Kim, S. (1967). Biochem. biophys. Res. Commun. 27, 479.

Perrie, W.T. \& Perry, S. V. (1970). Biochem.J. 119, 31.

Perry, S. V. (1952). Biochim. biophys. Acta, 8, 499.

Perry, S. V. (1955). In Methods in Enzymology, vol. 2, p. 582. Ed. by Colowick, S. P. \& Kaplan, N. O. New York: Academic Press Inc.

Perry, S. V. (1960). Biochem. J. 74, 94.

Perry, S. V. (1969). Proc. Symp. Physiology and Biochemistry of Muscle as a Food, Madison.

Perry, S. V. \& Zydowo, M. (1959). Biochem. J. 71, 220.

Richards, E. G., Chung, C. S., Menzel, D. B. \& Olcott, H. S. (1967). Biochemistry, Easton, 6, 528.

Rosen, H. (1957). Archs Biochem. Biophys. 67, 10.

Saide, J. D., Kayne, H. L. \& Ulbrick, W. C. (1968). Muscle Notes, no. 48.

Stone, D. (1970). Ph.D. Dissertation: University of Birmingham.

Tidwell, T., Allfrey, V. G. \& Mirsky, A. E. (1968). J. biol. Chem. 243, 707.

Trayer, I. P., Harris, C. I. \& Perry, S. V. (1968). Nature, Lond., 217, 452.

Trayer, I. P. \& Perry, S. V. (1966). Biochem. Z. 345, 87.

Udenfriend, S. (1966). Science, N.Y., 152, 1335. 